Evaluating an Innovative RedundancyRetraining Project: The Austrian Steel Foundation

Rudolf Winter-Ebmer

March 2001 


\title{
Evaluating an Innovative Redundancy- Retraining Project: The Austrian Steel Foundation
}

\author{
Rudolf Winter-Ebmer \\ University of Linz, Austria \\ WIFO Vienna, CEPR, London and IZA, Bonn
}

Discussion Paper No. 277

March 2001

\author{
IZA \\ P.O. Box 7240 \\ D-53072 Bonn \\ Germany \\ Tel.: +49-228-3894-0 \\ Fax: +49-228-3894-210 \\ Email: iza@iza.org
}

This Discussion Paper is issued within the framework of IZA's research area Project Evaluation. Any opinions expressed here are those of the author(s) and not those of the institute. Research disseminated by IZA may include views on policy, but the institute itself takes no institutional policy positions.

The Institute for the Study of Labor (IZA) in Bonn is a local and virtual international research center and a place of communication between science, politics and business. IZA is an independent, nonprofit limited liability company (Gesellschaft mit beschränkter Haftung) supported by the Deutsche Post AG. The center is associated with the University of Bonn and offers a stimulating research environment through its research networks, research support, and visitors and doctoral programs. IZA engages in (i) original and internationally competitive research in all fields of labor economics, (ii) development of policy concepts, and (iii) dissemination of research results and concepts to the interested public. The current research program deals with (1) mobility and flexibility of labor markets, (2) internationalization of labor markets and European integration, (3) the welfare state and labor markets, (4) labor markets in transition, (5) the future of work, (6) project evaluation and (7) general labor economics.

IZA Discussion Papers often represent preliminary work and are circulated to encourage discussion. Citation of such a paper should account for its provisional character. 


\section{ABSTRACT}

\section{Evaluating an Innovative Redundancy-Retraining Project: The Austrian Steel Foundation*}

This paper evaluates an Austrian manpower training program, which is highly innovative in its content and financing - and could therefore serve as a role model for other programs. In the late 1980s privatization and down-sizing of nationalized steel firms have lead to large-scale redundancies. A special Steel Foundation was created as part of a social plan. This Foundation acted like an independent training center, where displaced workers would spend relatively long training periods (sometimes several years), obtaining personality and orientation training, as well as formal education. The last step of the integrative program was placement assistance as well as assistance for creating one's own business. The Foundation was financed by (higher) contributions from unemployment insurance funds, by the previous firms themselves, as well as by a collectively-bargained special tax on the remaining workers in the Steel Firms. Moreover the trainees themselves would have to support the Foundation by depositing their redundancy payments.

In evaluating post-foundation economic performance I use days worked and wage growth. As a control group I take all other displaced workers from the firms who formed the Foundation, using Instrumental Variables to solve the selection problem. The results show considerable wage gains - even for a period of five years after leaving the Foundation - as well as improved employment prospects. Finally, a cost-benefit analysis is performed to assess the long-term success of the Foundation.

JEL Classification: H43, I21, J53, J65, J58

Keywords: Labor market programs, evaluation, cost-benefit analysis, Instrumental Variables

\section{Rudolf Winter-Ebmer}

University of Linz

A-4040 Linz, Austria

Tel.: +43732 $24688236(8237)$

Fax +4373224688238

Email: r.winterebmer@jk.uni-linz.ac.at

\footnotetext{
* This paper is based on a report commissioned by the Social Protection Department of the World Bank and financed by the Austrian trust fund; support from the Jubilee Funds of the Austrian National Bank is gratefully acknowledged. Bernd Dobesberger, Fritz Dorau, Brigitte Mühlböck, Josef Punz and Marius Wilk generously helped with data collection and insider information. Natalia Pakhomova assisted in data processing. Thanks to Amit Dar, Andrea Ichino, Robert Holzmann, Wilhelm Kohler, Alan Manning, Ken Mayhew, Steve Pischke, Josef Zweimüller as well as seminar participants in Oxford, the LSE, Vienna and Washington, D.C. for helpful comments. The views in this paper are those of the author and not necessarily those of the associated institutions.
} 


\section{Introduction}

Recent assessments of active labor market programs have come to very disillusioning conclusions: most of these programs (see Martin (2000) for the OECD, Heckman et al (2000) for the U.S. and Fitzenberger and Speckesser (2000) for East Germany) found only marginally positive impacts for specific groups in the population. This is very disappointing - given the big amounts of money having been spent on these programs.

It is also astonishing from a human capital theory point of view. As most active labor market programs are in fact manpower training programs, their success can in principle be compared to formal education programs. Here, recent assessments find in many countries increasingly higher returns to education, with rates between 7 and 10 percent per year of schooling completed (Card, 2000). These returns tend to be even higher when specific subgroups of the population are being targeted, which has been done by e.g. local average treatment effect estimates (Angrist et al., 1996): in many of these studies returns are estimated for subgroups which were for various reasons disadvantaged, lacked access to financial means or to schools nearby, etc. (Card, 1993, Ichino and Winter-Ebmer, 1999). As participants in manpower training programs often come from these disadvantaged groups, it is the more remarkable, that returns to manpower training programs and formal education are not compatible.

Given the very consistent findings of highly profitable investments in formal education results which are reinforced when endogeneity problems of school selection are taken into account, the question boils down to: why is it that manpower training programs are not always productivity enhancing. One reason could be the age structure of participants: Heckman (2000) argues convincingly that skill formation and retraining is much more difficult for students beyond the prime learning age. Another reason - which I will focus on - is the actual design of the manpower training program. To be successful for an adult training program it is not sufficient to provide a uniform quality of training like in school. Rather, a combination of reorientation, individualized training and job-search assistance is needed.

In this paper I portray an innovative policy measure for structural employment problems: the Austrian Steel Foundation, which started to operate in 1987. It was designed as an answer to structural change in Austrian steel industry, which was characterized by a strong regional concentration and a particular specificity of knowledge and training. ${ }^{1}$ The Foundation is unique

\footnotetext{
${ }^{1}$ See Davis et al. (1996, p. 112 f) for a picture of the restructuring process in the U.S. steel industry.
} 
in its purpose. $^{2}$ It tries to combine job-search assistance with psychological counseling, retraining and occupational re-orientation. It is also unusual in its broad-based financial structure. Aside from public money, part of the financing comes from trainees themselves, from the displacing firm as well as from the remaining part of the work force.

In the next section labor market institutions in Austria are presented, with a special emphasis on rules governing displacement as well as on social programs towards alleviating impacts of the severe steel crises on workers. In section 3, the organization of the Steel Foundation is presented focusing on the funding of the Foundation as well as the training concept, which stresses the longer-term view. Section 4 describes the data to evaluate the labor market effects of the Foundation. Improvements in employment and wages relative to a control group of displaced workers from the Steel Firms are used as the evaluation target. Section 5 aims at a cost-benefit analysis of the Foundation and section 6 concludes and explores conditions for successful retraining projects.

\section{Institutions in Austria and labor market policies}

In the aftermath of World War 2 the Austrian steel industry - together with major other parts of industry and banking - was nationalized, in part to prevent expropriation by the Russian Army. After mounting financial losses a new management took office, which resulted in a considerable and almost permanent re-organization in the firm structure starting in 1986, although substantial privatization of the steel industry did not occur until 1994. Between 1986 and 1988 alone, the number of workers in the steel industry was reduced by $23 \%$.

The combination of being a nationalized firm with heavy influence of politics and the unions, and a high regional and occupational concentration of the structural crisis made coping with the necessity of downsizing difficult. ${ }^{3}$ This explains the large number of passive and active labor market policies, which have been applied in this case. Moreover, job security provision is highly regulated in Austria. ${ }^{4}$

The Protection Against Dismissal Law applies to all firms with at least 5 employees and requires the approval of the works council in case of a layoff. Wrongful termination lawsuits are seldom and mostly result not in reinstatement but in the payment of a financial compensation.

\footnotetext{
${ }^{2}$ The U.S. Trade Adjustment Assistance (TAA) program, available since 1962, is one of the first comprehensive policy measures which combines job search assistance with re-training for a very specific group of workers (Decker and Corson, 1995).

${ }^{3}$ See Kerz (1991) for an analysis of firm strategies in the U.S. and European steel industries concerning subsidy levels, personnel policies and the occurence of social plans.
} 
General severance pay in the case of layoff - which was available only for white-collar workers before - has recently also been introduced for blue-collar workers and is determined by length of service and the wage level. Rules for mass redundancies require 30 days of notification to the employment office. Mass dismissals have increasingly been accompanied by a social plan agreed upon between management, unions and sometimes the government.

These relatively rigid labor relations called for a concerted action, i.e. an agreement between the management, the unions and eventually the government. Up to the early 1980s displacement of workers in Austria's nationalized industries was very uncommon, temporary overmanning problems were typically resolved by a combination of voluntary turnover e.g. exits into retirement, and temporary recruitment stops. From 1983 onwards, special early retirement programs were designed. Another measure was to increase maximum unemployment benefit duration for workers: Between 1988 and 1993, workers who were above age 50 and have lived and worked in so-called "crises-counties" (which included the main Steel Firms) could claim unemployment benefits for a longer period as compared to other job seekers. ${ }^{5}$

\section{Organization of the Steel Foundation}

During the biggest financial crisis of the Steel Firms in 1987 the Steel Foundation was founded. The organization and the financial structure of the Foundation were negotiated extensively between management and the works council. This corporatist character can be seen in subsequent agreements concerning wage bargaining, but also in the management of the Foundation itself. Three members of the works council together with three managers from the Steel Firms form the executive board of the Foundation.

Already in 1987 twelve firms started the Foundation, by 198822 firms had joined. Owing to restructuring and outsourcing processes, many new firms were founded in the next decade, so that by 199858 firms had participated, some of which are not active any more. ${ }^{6}$

\subsection{Funding and financial organization}

The financial organization of the Foundation is unique in a sense that all associated actors participate in funding: this includes the trainees themselves, the firms and the remaining workers

\footnotetext{
${ }^{4}$ Following Emerson (1988) it is amongst the most highly regulated countries in Europe.

${ }^{5}$ See Winter-Ebmer $(1996,1998)$ for an evaluation of this program considering unemployment duration and displacement of elderly workers.
} 
in these firms as well as the local government. This complicated financial structure can be understood as a structure to alleviate incentive problems of the associated groups. For instance, the financial participation of the remaining workforce can be interpreted as an efficient bargaining of the unions, they accept lower wages in exchange for an employment guarantee not necessarily on the shop floor alone but including the workers in the Foundation. The firms obviously have an incentive to deviate from this efficient bargaining solution - back to the labor demand curve; they do not do so, because the involvement of the local government, as well as the labor office make deviations very visible.

The Steel Firms contributed a one-time grant of $\$ 710,000$, a yearly allowance, as well as a subsidy-in-kind: training facilities and machinery at the shop floor, as well as educated trainers together with the personnel of the Foundation as such.

Trainees themselves had to deposit $50 \%$ of their contractual severance pay - up to a maximum of $\$ 7,100$. The interest thereof fell to the Foundation. The remaining workers in the Steel Firms paid $0.75 \%$ (up from 11/1989 only 0.25\%) of their gross wages into the Foundation. Moreover, the firms themselves augmented these "solidarity contributions" by $50 \%$ as a matching grant. (Steininger, 1993, p34). ${ }^{7}$ The early reduction in the contributions of the remaining workforce was caused by the relatively low number of trainees in the first years which led to significant reserve funds. These contributions of the remaining workforce were negotiated in a collective bargaining agreement, which was and still is binding for all workers. ${ }^{8}$

On the other hand, the trainees are allowed to collect unemployment benefits for a longer period of time while being a member of a Foundation. A new law in 1988 has increased potential unemployment duration from a maximum of 52 weeks to a period of 3 years (later 4 years). This extended duration is possible only for trainees who are members of a Foundation, which is formally licensed by the labor office. On top of this extended benefit duration, trainees receive a special scholarship, which initially amounted to $\$ 207$ per month. Due to an initiative of the Steel Firms' management, in 1993 the scholarship was increased to \$ 414 a month. The reason was that the management wanted to give incentives also for highly qualified workers to join the Foundation - which would lead to voluntary quits of more experienced and therefore highly-paid workers.

\footnotetext{
${ }^{6}$ See Winter-Ebmer (2001) for more details on the institutional and financial structure of the Foundation.

7 This matching is sensible, because the firms save on the employers' contributions to social security funds, which are approximately of this order.

${ }^{8}$ In fact, in 1987 collective bargaining in the metal industry resulted in a wage raise by $1.75 \%$. For workers in the Steel Foundation firms this raise was reduced by a special contract between management and works council to $1.0 \%$.
} 
Apart from interest from reserves and contributions from the local government, $43 \%$ of the budget in 1998 was contributed by the firms, only approximately $2-3 \%$ by the trainees themselves. $36 \%$ came from the wage restraint by the remaining workers. The rest $(18 \%)$ is paid again by the firms, but it corresponds roughly to saved social security contributions of the employers - owing to the lower wage bill. ${ }^{9}$

It is interesting to see that trainees, on the one hand, contribute money to the Foundation, but, on the other hand, they obtain a scholarship. Financially, the contribution of trainees can be considered largely as symbolic. It might have mattered, though, because trainees had to deposit their redundancy pay - which might have amounted to several months' pay - for a relatively long period. Having said this, it is always financially profitable for all workers to join the Foundation, once they loose their job. Why are only a small percentage of workers actually joining? I will give an answer to this question in section 4.2 as well as in the conclusions.

\subsection{Training and re-qualification}

Laid off workers who are accepted in the Foundation must commit themselves to a fulltime re-training program and obey the rules of the Foundation - otherwise they risk to get expelled. One of the rules is compulsory attendance in all training courses, which are in principle 38.5 hours a week. Other rules govern the choice - and possibly changes - of the educational and professional plan for the trainee; i.e. a trainee cannot unilaterally choose a professional goal, if the Foundation's management considers the goal as not marketable. The major difference between the Steel Foundation and other retraining programs is the sophisticated and long-term oriented view of re-qualification and occupational reorientation of workers. This is an important point regarding the permanent and regionally highly concentrated loss of jobs. Simply adding marginal improvements to the highly specialized skills of redundant steel workers seems inappropriate in such a situation.

The timing of a typical trainee in the Foundation can be described along the lines of Figure 1. All workers entering the Foundation undergo a six-week occupational orientation seminar, which should clarify the further steps: either direct outplacement and job-search, formal education or a project to start a new enterprise. Only $17 \%$ of trainees leave the Foundation very early or opt for outplacement without training. $49 \%$ of trainees choose occupational

\footnotetext{
${ }^{9}$ Financial report of the Foundation, 1998
} 
qualification, whereas $29 \%$ start (or continue) a formal education in schools or universities. Around $3.4 \%$ try to start a new firm

\subsubsection{Occupational orientation seminar}

The first six weeks are spent in small groups of 10-15 trainees together with a professional trainer, in most cases psychologists or counselors. The idea is to motivate the participants to take initiative and define - together with the trainer - an individual occupational and educational plan, which will be the basis for a new professional career. This task is challenging because almost $50 \%$ of trainees are above age 30, and have therefore already a fixed job profile, which is often difficult to change. Moreover, coming from a nationalized firm with de facto job guarantee might reduce initiatives for re-orientation.

With continuous psychological help - also from external institutions - the seminar starts with communication and social skills. Socio-psychological tests for occupational competence, together with an analysis of the past career and external labor market trends, shall provide the participant with a clearer view about his possible second career. Within these six weeks the participant must present a detailed and formal occupational and educational plan to the group and to officials from the labor office, which can in turn be corrected and changed by the Foundation's managers, but is binding from then on. The plan can mean immediate outplacement, re-qualification or the formation of a new business.

\subsubsection{Training programs}

Training can mean higher qualification in the previously practiced occupation or a complete re-orientation in a new field. The trainees can choose courses offered by the Foundation itself - mainly shorter language skills, mathematics, software and communication and presentation techniques. On the other hand, trainees can attend courses at established training organizations and also formal education at schools (night school) and universities. All training courses must be full-time training and require strict attendance and documentation in form of certificates. For some qualification measures - i.e. apprenticeship training - training-onthe-job is required. In these cases training places in firms on a voluntary basis are organized. Training - especially technical training as an apprentice - is also possible in the apprenticeshiptraining center of the original steel firm. 
Of those who do make a training plan, $65 \%$ choose occupational qualifications, whereas $35 \%$ take up formal education. The vast majority of those in occupational re-training receive training in technical occupations, followed by commercial ones. Similarly, most of those in formal education take up secondary technical schooling.

\subsubsection{New firm formation}

If a trainee designs a project for a new firm, (s)he will benefit from special assistance in the project planning and project management phase. The concept will get counseling from internal and external experts. The trainee can obtain special training measures necessary for firm formation, i.e. in the case a trade license is necessary, etc. The Foundation itself hosts a project center, where basic infrastructure like telecommunication services and administrative facilities are available.

Until 1998, 108 projects have been started; among them 44 have been successful. Most of the projects are in the field of consulting and services, but some concern also machinery and energy and environmental technology. A proper assessment of the success of the firm formation program is outside the scope of this paper.

\subsubsection{Outplacement}

The outplacement phase can come after a formal education or training or immediately after the occupational orientation seminar, if the individual does not want to change his occupational profile. It can last for up to four months; if no job is found, the individual has to redefine his target or leave the Foundation. In the outplacement phase assistance is given for regular jobsearch activities, which reach from software assistance for writing CVs and application letters to trade directories, access to lists of vacancies and the like. Presentation, communication and the use of new communication technologies is trained, IQ tests as well as personality tests are made and analyzed. Moreover, recruitment situations and job interviews are simulated and analyzed by video recording. 10

\footnotetext{
${ }^{10}$ See Davy et al. (1995) on the effectiveness of formal outplacement strategies.
} 


\section{Evaluation of the Foundation}

The evaluation will concentrate on direct impacts of the Foundation on employment and wages of participants. Other aims of the Foundation are not assessed. For instance, the management of the ongoing Steel Firms is also - or primarily - interested in the Foundation in order to assure a smooth process of restructuring and downsizing, which is unhindered by labor disputes and strikes $^{11}$. This is especially valuable because these firms have been formerly nationalized firms with implicit job-guarantees. As any other social plan, the Foundation alleviates large downsizing programs, which was the motivation for the management to discuss the Foundation concept in the first place. These aspects, as well as feedback effects on the local labor market, are very difficult to assess and are not investigated here.

The central problem of evaluation research is the counterfactual nature of the situation. ${ }^{12}$ The researcher wants to know what the wage or employment situation of the trainee would have been, had $\mathrm{s}(\mathrm{he})$ not taken place in the training program. As the trainee cannot be observed in this state, a suitable control group has to be used. In the literature, different control group concepts have been used: the trainee himself before the training (pre-post-comparison), a group of other comparable workers (classical control group approach) or completely matched trainee-control groups in a real social experiment framework. ${ }^{13}$ Moreover, with the exception of a perfect social experiment, selection into the program is a prime issue: participants can be expected to join the program exactly because they expect higher returns from the program than non-participants which will bias the evaluation results. ${ }^{14}$

\footnotetext{
${ }^{11}$ See e.g. the statement of a steel manager (Dipplinger, 1991, p.81), see also Seckauer (1997) who conducted interviews with unionists, members of the chamber of commerce and managers at the local employment office. On the other hand, union officials complain that downsizing will be too easy for firms and no strikes are possible any more (Seckauer, 1997, p. 53).

12 See Heckman, LaLonde and Smith (2000) for a discussion of basic issues, as well as a survey on the effectiveness of labor market programs in the U.S. See Dar and Gll (1995) for an assessment of transferability of retraining programs to countries in transition and Winter-Ebmer and Zweimüller (1996) for an evaluation of previous training programs in Austria.

${ }^{13}$ In accordance with the literature, feedback effects on local labor markets - especially indirect effects upon members of the control group are neglected. This procedure seems to be valid, given the relatively small number of trainees in each year as compared to the local labor market. See e.g. Heckman, Lochner and Taber (1998) who find big general equilibrium effects for a universal program in education.

14 Although many evaluations of the Steel Foundation have been done in the last 10 years, none of these has used a proper control-group setting. Some evaluations have looked only at the expectations of trainees at entry into the Foundation (Nigsch, 1995). Most other publications as well as official bulletins of the Foundation use the immediate exit status of trainees as a success criterion (Eder, 1997, Voest-Alpine Stahlstiftung, 1998): 72\% of trainees find a new job directly after leaving the Foundation. This measure can be problematic from an external point of view. It looks only at one point in time. Moreover, the duration of trainees in the Foundation is variable, and it ends by definition if the trainee finds a new job. Lechner and Reiter (1991) collected questionnaire information on 120 former trainees, who were asked about their current situation as compared to their pre-training situation in the steel firm. Due to high unionization in the nationalized firms, wage levels in the
} 


\subsection{Data}

In the following analysis I use all available data on trainees in the Steel Foundation from 1987 to 1998. Basic information on members of the Steel Foundation was received from the Foundation itself, corresponding employment histories were collected from the Social Security Administration and information about unemployment spells as well as educational attainment was matched from the Austrian Labor Office. I could use information for 2098 individuals (trainees), 38 persons of the original data could not be matched because of inconsistent social security numbers. As practically all data - except the information on specific training programs for the trainees - come from administrative data sources, high reliability can be assumed. These employment and income data serve the purpose of either being the basis for old age retirement pensions or the basis for the calculation of unemployment benefits in case of unemployment, which will reduce possible measurement errors.

The control group consists of all workers who worked with one of the Steel Firms, left them after 1986 and fell unemployed in the same or the next year. A unique firm identifier serves to collect these workers from the Social Security Administration files. Unfortunately not all firm identifiers could be received from the different local Social Security Administrations, because some small firms were not active anymore. ${ }^{15}$ Therefore I ended up with workers from 36 firms participating in the Foundation. 15,293 persons build the control group.

This control group is not the only possible choice. I could have used all workers having been dismissing by one of the participating firms. I excluded workers who did not claim unemployment benefits right after leaving these firms, i.e. those who found immediately a new job. Those who never fell unemployed are supposedly a positively selected group, whereas the value of the Steel Foundation - similar to any other labor market program - should be judged against the experience of those who are unemployed at some point in time. ${ }^{16}$ Figure 2 serves as a guideline as to which workers were included in the control group and which were not. As the data contain only the sum of workdays and unemployment days during a calendar year, but not the exact dates during the years, I chose the following procedure: Workers who did not claim

Steel Firms were generally relatively high, so that a displaced worker from one of these firms must expect considerable wage cuts if he starts a job with a firm in the private sector. Therefore, reliable assessments of the contribution of the Foundation on wage growth can only be made if an appropriate control group is used.

\footnotetext{
15 The problem was somewhat aggravated because all identifiers had to be anonymously transferred between 5
} different institutions. 
unemployment benefits (person 4) in the year after loosing the job with the steel firm were excluded, whereas those who did so at least in the following year (persons 1 and 2) were included.

How do I judge the success of the program? Most program evaluations look at the time spent unemployed or being in a program as the prime success indicator. This point of view is not appropriate for such a long-term oriented program. Here, the main intention is not to provide jobs as quickly as possible, but to assure medium and long-term job prospects. Therefore, the evaluation must concentrate on labor market indicators after leaving the Foundation and disregard the immediate exit from the Foundation as a success indicator. I define the calendar year following exit from the Foundation as the first year to start the evaluation process (year $t+1$ in Figure 2). Accordingly for controls, year $t+1$ will be the year after the first unemployment spell after leaving the Steel Firm. In order to properly address these long term aspects, I construct a five-year observation period for trainees and controls in such a way (see again Figure 2). ${ }^{17}$ In all evaluations to come I compare outcomes in year $\mathrm{t}+\mathrm{i}(\mathrm{i}=1-5)$ for trainees with outcomes in year $\mathrm{t}+\mathrm{i}$ for controls.

Table 1 presents basic statistics of the trainees and controls. Trainees are on average younger than displaced workers who did not join the Foundation. They have the same tenure in the steel firm. Trainees on average spend 18 months in the Foundation. The social security administration records only monthly gross incomes, up to a social security contribution ceiling. ${ }^{18}$ If workers are employed for less than a month in a firm, the administration calculates a hypothetical monthly income. Wages shown in Table 1 are real monthly wages based on 1986 ATS. There is some indication of selection processes as can be seen by previous wages. Trainees have considerably higher wages before redundancy as well as after. For both groups wages drop in the first year after the redundancy, but they regain lost ground later on. The number of employment days with different firms over a year was summed up to give an employment indicator. As all workers were typically employed yearlong in the Steel Firms before the redundancy only employment and unemployment days after redundancy are shown.

\footnotetext{
${ }^{16}$ For those who never fell unemployed crucial information about education, family situation and occupation is not available in any case.

17 One problem of this kind of analysis is that controls might be unable to find a job in year $t+1$, my first evaluation year, whereas trainees - who are taken out of the labor market for one and a half year on average will have enough time and assistance to locate a job immediately after the end of the Foundation's guidance. One can argue that this guidance is exactly the purpose of the Foundation - and should be checked correspondingly. This argument is less problematic, once I compare job market outcomes in up to five years following the training. Moreover, I also performed some sensitivity checks where I systematically compared year $\mathrm{t}+\mathrm{i}$ for the trainees with year $t+i+1$ for the controls. Regression results - which did not change the results qualitatively are available upon request.

${ }^{18}$ App. 5\% of displaced workers have wages above the social security contribution ceiling.
} 
Again, trainees have considerably higher employment days in all five years after separation. Likewise their number of unemployment days is significantly lower.

\subsection{Entry into the Foundation}

As there are high financial incentives to join the Foundation, it is astonishing that only $12 \%$ of eligible displaced workers actually did join. One reason may be the requirement for fulltime retraining which may discourage some workers who do not want to reorient their occupational position. The empirical model for entry into the Foundation can be written as follows:

$$
F_{i}^{*}=\alpha X_{i}+\varepsilon_{i}
$$

$$
\begin{aligned}
& F_{i}=1 \text { iff } \mathrm{F}_{\mathrm{i}}^{*} \geq 0 \\
& F_{i}=0 \text { iff } \mathrm{F}_{\mathrm{i}}^{*}<0
\end{aligned}
$$

where $F_{\mathrm{i}}$ is 1 if the individual joins the Foundation and zero else. $F_{i}^{*}$ is the latent

variable, $\mathrm{X}_{\mathrm{i}}$ is a vector of individual characteristics and $\alpha$ is a vector of parameters to be estimated. Assuming that the error term $\varepsilon_{\mathrm{i}}$ is standard-normally distributed, equation (1) specifies a probit model.

Results for the entry probabilities are contained in Table 2 for men and women separately. Mean entry rates for females are slightly lower as compared to men's. Age is an important factor. For males the age with the maximum entry probability is 31 years, for females 33 . Males at age 20 have approximately a 5 percentage points lower probability, those at age 45 have a 8 percentage points lower probability to join as compared to workers aged 31 at the time of displacement. More tenured male workers join the Foundation more frequently, as well as white-collar workers. Workers holding a technical or commercial middle school, but also those with a general High school as well as apprentices are most likely to join, whereas those with only elementary school are the least likely among the males. Foreign citizens are less likely to join whereas workers in metal occupations have the highest probabilities. Workers with health problems are less like to join the Foundation. These demographic characteristics of trainees correspond closely to those of trainees in publicly-financed trainee programs: young men, 
holding an apprenticeship from metal occupations are over-represented among trainees as compared to the unemployment pool at large (Blumberger et al. 1993, p. 96).

\subsection{Instrumentation strategy}

For the actual evaluation I restrict my sample to workers above 16 and below 53 years of age to avoid early retirement problems. Moreover, Foundation members who started a selfemployment career were excluded, because self-employed days are not registered in the data.

A prime concern in this kind of evaluation is the selection into the Foundation. Only around $12 \%$ of eligible displaced workers choose to participate. In principle they will do so, if their expected returns from participation exceed their expected costs. In practice, different arguments are possible why participants are not randomly selected among the displaced workers, and more importantly, why participants may have different post-training careers as non-participants would have had. Participants may have higher motivation to be re-trained and pursue further education. Given that the local unemployment rate was close to five percent, those who think they can easily find a new job may not take advantage of the Foundation in the first place and search for a job on their own. This group might as well be a group with better job market prospects.

Nigsch (1995) has investigated expectations and socio-demographic characteristics of the participants in the Foundation. ${ }^{19}$ More than $50 \%$ of trainees in both cohorts entered the Foundation because they wanted to start a new education or re-training, most of them expected primarily to get assistance in occupational re-orientation and education.

Out of 337 persons asked in 1995, 49\% got their first information on the Foundation by colleagues in the previous firm, $10 \%$ by a company newsletter and further $24 \%$ by shop stewards (Nigsch, 1995, p. 66). In rare cases they got information from outside the firm or from the labor office. Many workers complained that their actual displacement was not announced before the legally required date and that they got no - or only very late and hesitant information about the Steel Foundation (Lechner and Reiter, 1991, p.30). Moreover, in the early years local shop stewards did not accept the Foundation unequivocally. Unequal support and acceptance of the Foundation can mean that information channels were different in the various

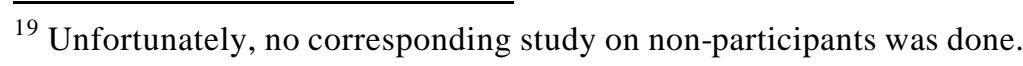


firms who were part of the Steel Foundation and in turn entry rates among displaced workers were different.

This observation gives us an idea for an Instrumental Variables strategy: As far as the previous affiliation with a specific firm has no influence on job market prospects in the future as can be expected because these firms basically grew out from one big enterprise - the firm identifiers can serve as a possible instrument to predict membership in the Foundation in order to cope with the crucial selectivity problem. Therefore, I add 32 firm identifiers as dummy variables in the entry equation. These firm dummies increase the explanatory power of the entry regression in Table 2 considerably - for males and for females.

Another instrumentation strategy relies more directly on information channels. Prospective Foundation entrants will get their information from former colleagues, who left the firm one period ago and joined the Foundation. Following this argument, I include the proportion of redundant workers in each firm and each year who joined the Foundation as an instrument for individual entry rates. As the firm entry rate in a period is just added up by the individuals' entry rates from the same period, I lagged the instrument by one year. Note, that this instrument varies by firm identifier and year. These instruments influence entry significantly, whereas no impact of affiliation with a specific firm on subsequent job market careers should be expected. Likelihood ratio tests for inclusion of the two sets of instruments in the entry equation are presented in Table 2. For men, a ten percentage points increase in the past entry rate of the firm increases the individual entry probability by 2 percentage points and by 0.8 percentage points for women.

Heckman, LaLonde and Smith (2000, p.93) argue that an Instrumental Variables approach will be invalid, if individuals base their participation on idiosyncratic gains from the treatment. They frame their critique for the example of using distance-to-college as an instrument for schooling (Card, 1993). If returns to college are heterogeneous among students, the instrument distance-to-college will shift participation, but, on the other hand, those who do go to college from more distant places are those who have relatively large returns to college, large enough to offset the higher cost of participation. This argument would therefore invalidate the instrument. For our case of better information in different firms, this argument should not be important, because those who have less information do not have higher costs of participating in the Foundation. Insofar as those who have less information about the Foundation do in fact need a higher motivation or higher expected returns to join anyway, returns by IV methods will be biased upwards. 


\subsection{Employment effects}

Employment effects of the Foundation will be checked in the five years following exit from the Foundation. The dependent variable is the number of employed days $\left(\mathrm{Y}_{\mathrm{i}}\right)$ per calendar year, which will be explained by affiliation with the Foundation $\left(\mathrm{F}_{\mathrm{i}}\right)$ and a vector of other explanatory variables, which are basically demographic and occupational characteristics measured at the previous firm $\left(X_{i}\right.$, see footnote to Table 3). Due to lower (0) and upper censoring (365) a Tobit model is appropriate, where $Y_{i}^{*}$ is the underlying latent variable.

$$
\begin{aligned}
& Y_{i}^{*}=\beta_{0} F_{i}+\beta X_{i}+\eta_{i} \\
& Y_{i}=Y_{i}^{*} \quad \text { if } 0 \leq Y_{\mathrm{i}}^{*} \leq 365 \\
& \mathrm{Y}_{\mathrm{i}}=0 \quad \text { if } \mathrm{Y}_{\mathrm{i}}^{*}<0 \\
& \mathrm{Y}_{\mathrm{i}}=365 \text { if } \mathrm{Y}_{\mathrm{i}}^{*}>365
\end{aligned}
$$

In Table 3 employment gains of trainees versus controls are presented using the simple Tobit as well as the two Instrumental Variables Tobit ${ }^{20}$ models. As I can observe up to five years after completion of the training episode, in a first step I merged all observations, which gives an average impact of the Foundation in the years one to five. Dummy variables for year $\mathrm{t}+\mathrm{i}$ are added as well as year dummies for the year of exit from the Steel Firm. Differential impacts in the first five years after training are investigated in Table 4. For the interpretation of the Tobit coefficients it must be noted that the change in the censored outcome $\mathrm{Y}_{\mathrm{i}}$ is relevant here, because workers cannot possible work more than 365 days or less than one day per year. The change in actual days worked due to participating in the Foundation $F_{i}$ is given by (Long, 1997, 209)

$$
\frac{\partial E\langle Y \mid X\rangle}{\partial F}=\operatorname{Pr}\langle\text { Uncensored } \mid X\rangle \beta_{o}
$$

In the simple Tobit estimate employment of trainees is 45 days higher as compared to the control group. The program impact is even higher if the Instrumental Variables approach is used. Irrespective what Instrumental Variables strategy is chosen, trainees work 70-80 days

\footnotetext{
${ }^{20}$ I used the STATA module kindly provided by Jonah Gelbach (Univ. of Maryland, College Park).
} 
longer per year than controls. As the sample is mainly comprised of men, the impact for men only is rather similar. For females program impacts are more imprecisely estimated: Whereas the simple Tobit impact is significant with 35 days, the two IV estimates range between 5 and 57 days. These inconsistencies can arise because fewer women are in the sample and even fewer participate in the Foundation. Generally, higher impacts for the IV regressions suggest that the trainees are selected from the a-priori less successful workers.

As the primary sample is rather big, we can look at differential impacts of the Foundation on different population groups. I present results for age groups and income classes by quartiles. An interesting age pattern arises: the youngest workers gain the least, whereas workers above 27 have the highest employment gain from the training in the Foundation. For workers below age 27 the simple Tobit results are indeed positive and significant, but not the IV results. This suggests that younger workers have less problems in re-orienting their occupational career, whereas workers above age 27 need more assistance - most probably they had also higher tenure with the steel firm in the first place, i.e. a more firm-specific human capital. Here the difference between Tobit and Tobit-IV results suggests, that among the young workers, trainees are positively selected, whereas among the older workers, a negative selection into the Foundation takes place.

In terms of past incomes in the Steel Firms, the results are more homogeneous. Most training coefficients are positive and significant (except one negative insignificant coefficient). There is no obvious pattern by income quantiles, if ever the effect is smaller for the third quantile.

Due to the long duration of the Foundation and the richness of the data, it is possible to look at medium-term effects of the training measures. Table 4 differentiates training impacts separately for the first five years after completion of the Foundation. All fifteen regression coefficients are significantly positive, which means that the trainees profited from the comprehensive support from the Foundation even five years after leaving. The effect is only slightly declining over time, when the Tobit or Tobit-IV-1 estimator is used, but not in the case of Tobit-IV-2.

\subsection{Income effects}

After inquiring the employment effects of the Foundation I turn now to income effects. As is typical for administrative data, only monthly incomes are available. The only information about working hours is a part-time indicator, which is used as a control variable in the earnings 
regression. Given the use of monthly earnings, the following results have to be interpreted with care, because possible impacts of the Foundation on earnings could be caused by higher productivity as such, which is reflected in higher hourly wages, but also by an increase in labor supply, i.e. hours per week. The problem seems to be less problematic for men, who work predominantly a 38.5 hours week. Moreover, part-time work for males in the steel industry is extremely rare. Nevertheless to reduce biases by including workers with reduced hours or apprentices, I eliminated workers who had a base monthly income below \$ 570 (in 1986 real \$), which is approximately $3 \%$ of the sample ${ }^{21}$.

Incomes have to be seen relative to past incomes in the Steel Firms. Therefore I use wage growth as a performance ndicator. Again, there is a problem of censoring. For those, who were above the social security contribution ceiling before displacement, wage growth is impossible to measure, it cannot even be bounded. Therefore I restrain the analysis to workers whose wages were lower than $2 \%$ below the contribution ceiling in the old firm - to allow for some measurement error. For these workers I can construct earnings growth between period $\mathrm{t}+\mathrm{k}$ and period $\mathrm{t}$ as $\left(\mathrm{w}_{\mathrm{t}+\mathrm{k}}-\mathrm{w}_{\mathrm{t}}\right) / \mathrm{w}_{\mathrm{t}}$ :

$$
\left(\frac{w_{t+k}-w_{t}}{w_{t}}\right)^{*}=\gamma_{0} F_{i}+\gamma Z_{i}+\mu_{i}
$$

$$
\begin{aligned}
& \frac{w_{t+k}-w_{t}}{w_{t}}=\left(\frac{w_{t+k}-w_{t}}{w_{t}}\right)^{*} \text { if } w_{t+k} \leq C_{t+k} \\
& \frac{w_{t+k}-w_{t}}{w_{t}}=\frac{C_{t+k}-w_{t}}{w_{t}} \text { else }
\end{aligned}
$$

Still, the censoring problem in the second period has to be taken into account, which is the case if earnings in the second period are above $\mathrm{C}_{\mathrm{t}+\mathrm{k}}$ - the contribution ceiling -, which varies over time. This results in a Tobit model with varying upper limits. As the censoring is an unintentional censoring in this case, i.e. wage growth above the social security ceiling could well be possible, but cannot be observed in the sample, the right interpretation of the estimates is to

\footnotetext{
21 Apprentices could not join the Foundation immediately after completion of their apprentice training, but they could in principle be part of the control group. This earnings limit should also eliminate apprentices from the control group.
} 
use changes in the latent outcome $\left(\frac{w_{t+k}-w_{t}}{w_{t}}\right)^{*}$ as driven by participation in the Foundation $\mathrm{F}_{1}$. The coefficient $\gamma_{0}$ itself is therefore the appropriate marginal effect.

The impact of the Foundation on earnings growth is on average a gain of 5 percentage points, when simple Tobit methods are used (Table 5). The impact rises to 6-7 percentage points when IV methods are applied. Again, the higher impacts from Instrumental Variables estimates suggest that participants are negatively selected. The impact of the Foundation is rather similar for both genders, but less significant for females. It must be noted, though, that there could be still a problem with working hours for females, if one looks at the high mean earnings growth of $14 \%$.

The pattern for the different age groups is very interesting. Very high effects are measured for young workers below age 22, still highly positive effects for those below age 37, but no positive impact can be found for workers above age 36. Again, hours effects could in part influence the very high impact for workers below age 22. This interpretation seems to be consistent with the impacts by income quantiles. Here, the highest impact is below the median of the income distribution of the displaced workers, whereas no notable impact can be found for those above the median. Even if some of these coefficients should be perturbed by hours effects, the positive effect of the Foundation is just evident in a different way: instead of increasing productivity as such, workers are encouraged to work longer hours. From the point of view of social policy, the effects can be similarly assessed. ${ }^{22}$ One problem for this evaluation strategy could be the exclusion of the high-wage workers due to the censoring problem. Given that no positive impact is found for high-wage workers, the general impact could be lower, if all highwage workers would have been included in the estimation.

Finally, we can investigate if the impact of the Foundation on monthly earnings is fading over time. Within the five years after completion of the training, no fading can be found (Table 6). This is re-assuring if the impact is to be interpreted as a productivity effect: there is no reason to believe, that a higher productivity of a worker - brought about by formal schooling or training - should disappear over time.

An average return of 5-7 percentage points higher wage growth for trainees has to be compared to returns to formal education in Austria. Fersterer and Winter-Ebmer (2000) estimate returns to an additional year of education between 1981 and 1997 in the range of 7-10\%, slightly

\footnotetext{
${ }^{22}$ These patterns practically reinforce the general earnings pattern for these groups after displacement. Whereas the whole group of workers in the first quartile (the youngest) experience very high earnings growth, those above the median (also those above age 36) experience on average declining wages in this five year period.
} 
falling over time. How does the return to the training in the Foundation compare to this? Trainees stay on average 18 months in the Foundation, thereof 6 weeks of occupational orientation and up to 4 months of outplacement, which leaves roughly more than a year for real full-time training. The return to this year of training compares well with the returns to formal education. $^{23}$

\section{Cost-Benefit analysis}

Due to its comprehensive and long-term oriented structure, sizable positive employment and wage effects of the Steel Foundation could be found. Therefore, it seems useful to compare formally costs and benefits of the Foundation in a long-term view. This is particularly appropriate here, because the benefits of the Foundation are estimated for as long as five years after quitting the training scheme. Such a formal cost-benefit-analysis is only rarely done in typical evaluation studies, mainly because in most cases the measured benefits are small or zero in the first place. It should be noted though, that the costs and especially the benefits in Table 7 should be seen as approximate figures only, which hinge on a number of approximations and assumptions. They should give a basic view of the associated dimensions only.

Costs and benefits are measured in Millions of real Dollars (base 1998). Costs are basically taken from the books of the Foundation, whereas the benefits are extrapolated and discounted life-time gains from the Foundation based on the regressions in Tables 3 and 5. Some of the costs are only approximated, because the costs were not directly borne by the Foundation or the books were not differentiated enough for a proper calculation. For benefits in general lower bounds of the estimates were used, together with some sensible assumptions for the behavior of trainees after the five year period they were observed in the data.

The total costs borne by the Steel Firms themselves are 25.1 Million Dollars. This sum reduces to 20.6 Millions if the contribution to the Foundation due to the matched wage restraint of the workers is excluded. This sum corresponds to the reduced contributions to social security funds, the firms can save because of the lower wage bill. The remaining workforce paid 9 Million Dollars by reducing their wage demands during the whole period. The contributions of the trainees themselves had to be approximated, because no actual figures were available. As the trainees had to deposit their redundancy payments, I calculated a maximal interest loss by using a five percent interest rate and the maximum deposit of $\$ 7200$ and added interest lost on

\footnotetext{
${ }^{23}$ Results for different types of training in the Foundation are contained in Winter-Ebmer (2001).
} 
voluntary redundancy pay. Moreover, trainees have to incur opportunity costs due to lost income during participation. These costs can only be estimated as average wages minus mean unemployment benefits and scholarship. Likewise, public subsidies consisted of direct subsidies from the local government plus extended unemployment benefit duration for trainees - with exact figures only for the former. For the latter I assumed 13 months of additional receipt of unemployment benefits (18 months duration in the Foundation minus five months average benefit duration for workers in the steel industry) and a mean benefit level of $\$ 640$ per month. These "hidden" costs of the Foundation - together with lost taxes on the opportunity costs of trainees - increase the public subsidies to 21.8 Million Dollars, which is exactly one third of total costs of 66.9 Millions.

The calculation of benefits is much more difficult, because possible benefits from participation can be felt throughout the working life of the trainees. A proper life-time calculation of benefits seems impossible for most evaluation studies, because in most cases nothing is known about the time path of the benefits. Here, I can observe participants for at least five years after exiting the Foundation and can therefore estimate treatment effects for the first five years after training. Interestingly, the treatment effects both for wage growth and for employment do not diminish over these five years (see Tables 4 and 6). This is not particularly astonishing for wage growth, because if the training served to increase productivity of trainees, wages should be permanently higher thereafter. It is more remarkable for employment effects, where training could serve as a crises intervention program with (hopefully) high short-run effects but not so high long-run effects.

As the typical trainee enters the Foundation at age 31, I take 30 years as the time period for the further working life. A variant of the calculation takes only 10 years as the period where positive wage gains from training are received. I use the lowest regression result of 5\% wage gain, together with a discount rate of $4 \%$ over time. ${ }^{24}$ Note that this discount rate is rather high, because it should also take possible wage growth over these 30 years into account. The proper "nominal" discount rate must therefore be $4 \%$ plus the expected long-term wage growth. In the higher scenario, wage gains are 42 Millions, in the lower scenario 24 Million Dollars. For employment gains I assume that positive employment gains are reached only in the first 10 years. Again, the lowest Tobit measure of 45 days from Table 3 is used and the employment gain is transformed into income by using mean incomes from the sample. This results in an employment gain corresponding to 51 Million Dollars.

\footnotetext{
${ }^{24}$ The calculation takes into account that the workers in my sample work typically only 300 days per year.
} 
The total benefits vary according to my assumptions between 75 and 93 Million Dollar and are considerably above the total costs. Again, it has to be said that the amount of benefits is highly dependent upon the assumptions I have made. Let us assume that wage and employment gains would be present only in the first five years - the period where they have been properly estimated from the available data -, even in that case the benefit amount would be close to the total costs.

Another cost-benefit analysis can be made for the public. For the public only the costs borne by the local government and the increased benefit duration are important, which amounts to 21.8 Million Dollars. The wage and employment gains of the Foundation bring forth sizable revenues from taxes. For this calculation I took a marginal tax rate of $41 \%$ and included also increased contributions to unemployment and health insurance (but not old-age pension insurance). Using the higher measure for wage gains (a), we receive a tax increase of 51 Million Dollars which is considerably higher as the public costs of 22 Millions. In a strict calculation we should also take into account lower public expenditures due to reduced unemployment of the trainees in the future. Following the calculated employment gains shown above, these reduced unemployment costs would add up to further 17 Million Dollars in the first 10 years. So it seems fair to say, that the public cost-benefit analysis should be positive irrespective of the assumptions used. Moreover it seems highly probable that the total cost-benefit calculation is also positive, but here the margin is somewhat smaller and, therefore, the degree of confidence must be somewhat lower.

A final cost-benefit calculation concerns the value of the Foundation to the Steel Firms themselves. Several answers are possible. The firms can use the Foundation as a subsidized training and recruitment reservoir. In fact, ten percent of trainees were later recalled into one of the Steel Firms. A more realistic assumption is that the Foundation can serve as a public relations project in order to facilitate the downsizing necessities. For this supposition speaks the history of the Foundation: the management of the Steel Firms tried to strike a deal with the unions to make the downsizing possible in the first place, the management initiated an increase in the scholarship for trainees in order to induce more highly-paid workers to join. Moreover, the culture of "no-dismissals" and the high unionization in the Steel Firms would have made mass layoffs practically impossible without strikes and considerable social unrest. If the Foundation is, accordingly, seen as a social plan, how costly is it? Given the number of redundancies, we can calculate costs per laid off worker. In my sample I have 17,391 workers who were dismissed by the Steel Firms in the period 1988 to 1998 and (!) fell unemployed immediately after the dismissal. In general some people switch to a new job without an 
intervening unemployment spell, which would increase the (unobserved) number of actual redundancies. If we just consider the 17,391 displaced persons we can get an upper bound for the costs of downsizing: using the Steel Foundation as an instrument to facilitate the downsizing had costs of 1443 Dollars per redundant worker at a maximum, a relatively low amount to buy constantly good labor relations in hard times. ${ }^{25}$

\section{Conclusions}

This evaluation has looked at employment and wage gains due to participation in an innovative Austrian retraining project: the Steel Foundation. In the period of five years after exiting the Foundation, trainees seem to be successful in several respects: they can achieve higher wages, they have also better employment prospects as compared to the control group. Whereas employment effects are noticeable mainly for the old workers, wage gains are found only for young and low-wage workers. This points to one problem of the analysis: As wage gains could not be calculated for high-wage workers because of data problems, measured wage gains could found to be biased upwards, if the whole group of displaced workers could be observed.

Moreover, in a cost-benefit analysis, it seems to be that costs are significantly lower than discounted long-term benefits; this is true for costs at large, but also more narrowly for public expenditures and public returns. For the Steel Firms themselves, the Foundation seems to be a relatively cheap project to get away with a mass dismissal of steel workers. Some questions remain to be answered: why do so few eligible workers participate in the Foundation, given that their private return is so high? One answer to this question could be the strict regulations of the Foundation: members have to commit to a supervised occupational re-orientation work-shop which might be embarrassing because of the psychological assessment of one's qualifications and motives. They also have to commit to a full-time retraining program which will evidently be more stressfull than, say, being unemployed for a few weeks. Another reason can lie in time preferences of the individuals. The benefits of the Foundation - which are found to be substantial - do not accrue before completing the retraining and have to be accumulated over more than 10 years. On the other side, costs of participating - which are mainly opportunity costs for lost income - accrue immediately. If people are impatient, the immediate costs will weigh more heavily.

\footnotetext{
${ }^{25}$ In this calculation other costs like redundancy payments as such were not included. But this analysis considers correctly only the marginal costs per dismissal caused by the Foundation.
} 
What is the special feature of this Foundation, that makes it more successful than other projects? One answer can lie in the comprehensive and long-term direction of the occupational re-orientation and re-training scheme. This long-term orientation will allow a closer examination of personal qualifications and also more generous and radical career changes. Another advantage seems the close interaction between occupational (re-)orientation, training and jobsearch counseling. The immediate and consistent effort in the first weeks to keep the workers mentally attached to the labor market might overcome another problem which might arise in the case of hyperbolic discount rates: If workers have hyperbolic discount rates - i.e. they discount the immediate future higher than the more distant future - more impatient workers have been found to reduce search effort and stay unemployed longer. $^{26}$ The first weeks of an unemployment spell may therefore be very important in order not to lose contact with the labor market. Another reason can lie in the spirit of the organization; the cooperative character starting with the financial structure, the governance of the Foundation and the program - can possibly improve motivation of the participants and facilitate a self-determined learning environment. The financial structure - with sizeable contributions by the Steel Firms and the remaining workers - will foster closer monitoring of the Foundation by both management and the unions. Both "donors" have something to lose: the management wants to continue with the wage-cut the unions have agreed, whereas the unions have to justify this wage-cut towards its members.

Can this program be extended to other regions like developing countries or countries in transition where restructuring processes in major industries often occur? One important limitation is for the downsizing firms to remain on the market - otherwise the organization and financing of the Foundation cannot be done in such a way. Another issue concerns the local environment: a functioning local infrastructure is needed, which can, on the one hand, finance long-term oriented labor market policies, on the other hand, it must be able to offer a diversified set of training slots at different institutions to allow a highly individualized re-training.

\footnotetext{
${ }^{26}$ More impatient workers are expected to search less, but also to accept lower wage offers. In the case of hyperbolic discounting the search effect dominates. See DellaVigna and Paserman (2000) for an empirical test.
} 
Table 1: Basic statistics of trainees and controls

\begin{tabular}{|c|c|c|c|c|c|}
\hline \multirow{2}{*}{\multicolumn{2}{|c|}{ Mean duration of training }} & \multicolumn{2}{|c|}{ Trainees } & \multicolumn{2}{|l|}{ Controls } \\
\hline & & 1.48 & $(1.14)$ & - & \\
\hline \multicolumn{2}{|c|}{ Age at redundancy } & 31.08 & (9.94) & 35.83 & $(13.67)$ \\
\hline \multicolumn{2}{|c|}{ Tenure in steel firm } & 7.72 & $(6.51)$ & 7.74 & $(8.08)$ \\
\hline \multicolumn{2}{|c|}{$\begin{array}{l}\text { Last wage in steel firms } \\
\text { (real ATS per month) }\end{array}$} & $18,979.0$ & $(5039.7)$ & $17,747.7$ & $(5330.3)$ \\
\hline \multicolumn{2}{|c|}{ Wage $_{\mathrm{t}+1} *$} & $18,415.6$ & $(4986.8)$ & $16,230.5$ & $(5530.6)$ \\
\hline \multicolumn{2}{|c|}{ Wage $_{\mathrm{t}+2} *$} & $18,663.5$ & $(5175.3)$ & $16,979.9$ & $(5706.4)$ \\
\hline \multicolumn{2}{|c|}{ Wage $_{\mathrm{t}+3} *$} & $18,943.1$ & $(5362.5)$ & $17,552.5$ & $(5820.9)$ \\
\hline \multicolumn{2}{|c|}{ Wage $_{\mathrm{t}+4} *$} & $19,522.6$ & $(5457.3)$ & $18,018.5$ & $(6031.9)$ \\
\hline \multicolumn{2}{|c|}{ Wage $_{\mathrm{t}+5} *$} & $19,635.7$ & $(5686.6)$ & $18,057.6$ & $(6326.9)$ \\
\hline \multicolumn{2}{|c|}{ Employed days $t+1$} & 274.6 & $(131.7)$ & 199.6 & $(158.1)$ \\
\hline \multicolumn{2}{|l|}{-"- } & 296.7 & (121.9) & 216.7 & $(157.7)$ \\
\hline -"- & $t+3$ & 301.6 & (120.6) & 226.9 & $(156.1)$ \\
\hline -"- & $\mathrm{t}+4$ & 299.9 & $(123.0)$ & 240.4 & $(153.5)$ \\
\hline -"- & $\mathrm{t}+5$ & 296.7 & (126.7) & 253.5 & $(147.3)$ \\
\hline \multicolumn{2}{|c|}{ Unemployed days ${ }_{t+1}$} & 71.9 & $(115.2)$ & 87.1 & $(133.4)$ \\
\hline -"- & $t+2$ & 54.7 & (108.9) & 85.1 & (129.7) \\
\hline -"- & $t+3$ & 50.6 & (107.1) & 76.2 & $(122.0)$ \\
\hline -"- & $\mathrm{t}+4$ & 48.5 & $(107.2)$ & 71.3 & $(122.3)$ \\
\hline -"- & $\mathrm{t}+5$ & 40.2 & (98.6) & 60.9 & $(114.1)$ \\
\hline
\end{tabular}


Table 2: Entry into the Foundation ${ }^{27}$

\begin{tabular}{|c|c|c|}
\hline & Males & Females \\
\hline Age & $0.026 \quad(0.002)$ & $0.024 \quad(0.004)$ \\
\hline $\mathrm{Age}^{2} / 100$ & $-0.042 \quad(0.002)$ & $-0.036(0.006)$ \\
\hline $\begin{array}{l}\text { Tenure in steel firm } \\
\text { (years) }\end{array}$ & $0.016(0.001)$ & $0.007 \quad(0.003)$ \\
\hline Tenure in steel firm ${ }^{2} / 100$ & $-0.059(0.007)$ & $-0.029(0.014)$ \\
\hline Married (0/1) & $-0.024 \quad(0.006)$ & $-0.036(0.010)$ \\
\hline \# of children & & $-0.019(0.009)$ \\
\hline \multicolumn{3}{|l|}{$\begin{array}{l}\text { Education: base } \\
\text { compulsory }\end{array}$} \\
\hline - apprentice & $0.146(0.064)$ & $0.128 \quad(0.101)$ \\
\hline - master & $0.168 \quad(0.055)$ & $0.166(0.121)$ \\
\hline - technical middle school & $0.376(0.110)$ & - \\
\hline - comm. middle school & $0.270 \quad(.0107)$ & $0.525 \quad(0.261)$ \\
\hline - general High school & $0.218(0.108)$ & $0.149 \quad(0.140)$ \\
\hline - technical high school & $0.017 \quad(0.050)$ & - \\
\hline - comm. High school & $0.081 \quad(0.064)$ & $0.099(0.126)$ \\
\hline - other high school & $0.069 \quad(0.072)$ & $0.043(0.095)$ \\
\hline - university & $0.085(0.066)$ & $-0.015(0.057)$ \\
\hline - missing & $0.186(0.090)$ & $0.027 \quad(0.092)$ \\
\hline Foreign citizen $(0 / 1)$ & $-0.031 \quad(0.012)$ & $-0.053(0.013)$ \\
\hline White-collar worker $(0 / 1)$ & $0.032(0.008)$ & $-0.024(0.014)$ \\
\hline Part-time worker $(0 / 1)$ & - & $-0.046(0.012)$ \\
\hline \# jobs since 1972 & $-0.003(0.001)$ & $-0.003(0.001)$ \\
\hline $\begin{array}{l}\text { Hard-to-place because of } \\
\text { health problems }(0 / 1)\end{array}$ & $-0.026 \quad(0.008)$ & $-0.028(0.013)$ \\
\hline Firm size/1000 & $-0.012(0.002)$ & 0.001 \\
\hline Occupation: base metal & & - \\
\hline - Service & $-0.058 \quad(0.007)$ & $-0.118(0.013)$ \\
\hline $\begin{array}{l}\text { - Other production } \\
\text { worker }\end{array}$ & $-0.034 \quad(0.006)$ & $-0.069(0.009)$ \\
\hline - Trade & $-0.048 \quad(0.007)$ & $-0.077(0.008)$ \\
\hline - Technician & $-0.030 \quad(0.008)$ & $-0.058(0.011)$ \\
\hline - Administration & $-0.040 \quad(0.007)$ & $-0.153(0.051)$ \\
\hline $\mathrm{N}$ & 14545 & 2846 \\
\hline Mean entry probability & 0.123 & 0.097 \\
\hline Pseudo $\mathrm{R}^{2}$ & 0.189 & 0.152 \\
\hline $\log \mathrm{L}$ & -2632.5 & -440.6 \\
\hline $\begin{array}{l}\text { LRT for inclusion of Steel } \\
\text { Firm dummies }\end{array}$ & 431.8 & 78.8 \\
\hline $\begin{array}{l}\text { LRT for inclusion of past } \\
\text { firm-level entry rate }\end{array}$ & 147.9 & 11.2 \\
\hline
\end{tabular}

\footnotetext{
${ }^{27}$ Marginal effects from a univariate probit regression, LHS is entry into the Foundation. All RHS variables are measured at the time of redundancy, standard errors in parenthesis. 11 time dummies not reported.
} 
Table 3: Employment gains (days per year) of trainees vs. controls (average effects in year one to five after training $)^{28}$

\begin{tabular}{|c|c|c|c|c|c|}
\hline Group & $\mathbf{N}$ & $\begin{array}{c}\text { Mean } \\
\text { employment } \\
\text { days per year }\end{array}$ & Tobit & Tobit - IV-1 & Tobit - IV-2 \\
\hline All & 39318 & 232.8 & $\begin{array}{l}44.78 \\
(2.75)\end{array}$ & $\begin{array}{l}79.96 \\
(9.22)\end{array}$ & $\begin{array}{c}73.8 \\
(13.75)\end{array}$ \\
\hline Men & 32150 & 235.4 & $\begin{array}{l}43.97 \\
(2.91)\end{array}$ & $\begin{array}{l}67.39 \\
(9.46)\end{array}$ & $\begin{array}{c}55.78 \\
(14.34)\end{array}$ \\
\hline Women & 7168 & 220.9 & $\begin{array}{l}35.14 \\
(7.31)\end{array}$ & $\begin{array}{c}5.49 \\
(27.53)\end{array}$ & $\begin{array}{c}57.79 \\
(37.99)\end{array}$ \\
\hline $\mathrm{Age}^{29}<22$ & 9643 & 254.3 & $\begin{array}{l}32.94 \\
(5.87)\end{array}$ & $\begin{array}{c}-2.94 \\
(17.51)\end{array}$ & $\begin{array}{l}-20.77 \\
(29.36)\end{array}$ \\
\hline Age $22-26$ & 10256 & 259.1 & $\begin{array}{l}38.26 \\
(5.51)\end{array}$ & $\begin{array}{c}33.34 \\
(16.53)\end{array}$ & $\begin{array}{c}39.93 \\
(27.02)\end{array}$ \\
\hline Age $27-36$ & 9424 & 273.5 & $\begin{array}{l}14.11 \\
(5.09)\end{array}$ & $\begin{array}{c}81.81 \\
(16.32)\end{array}$ & $\begin{array}{c}98.92 \\
(22.22)\end{array}$ \\
\hline Age $>36$ & 9995 & 146.6 & $\begin{array}{l}41.31 \\
(4.89) \\
\end{array}$ & $\begin{array}{c}81.52 \\
(15.19) \\
\end{array}$ & $\begin{array}{c}53.78 \\
(23.71) \\
\end{array}$ \\
\hline \multicolumn{6}{|l|}{ Previous Wage } \\
\hline $1^{\text {st }}$ quartile & 9641 & 245.5 & $\begin{array}{l}31.32 \\
(5.75)\end{array}$ & $\begin{array}{c}52.96 \\
(17.70)\end{array}$ & $\begin{array}{c}93.69 \\
(24.94)\end{array}$ \\
\hline $2^{\text {nd }}$ quartile & 9623 & 247.9 & $\begin{array}{l}35.38 \\
(5.13)\end{array}$ & $\begin{array}{c}60.55 \\
(13.56)\end{array}$ & $\begin{array}{c}75.56 \\
(19.86)\end{array}$ \\
\hline $3^{\text {rd }}$ quartile & 9606 & 224.6 & $\begin{array}{l}35.26 \\
(5.23)\end{array}$ & $\begin{array}{c}47.60 \\
(17.22)\end{array}$ & $\begin{array}{c}-5.89 \\
(27.20)\end{array}$ \\
\hline $4^{\text {th }}$ quartile & 10456 & 214.3 & $\begin{array}{l}67.44 \\
(5.66)\end{array}$ & $\begin{array}{c}77.38 \\
(24.41)\end{array}$ & $\begin{array}{c}78.15 \\
(38.89)\end{array}$ \\
\hline
\end{tabular}

${ }^{28}$ Same control variables as in Table 4 plus 4 dummies for the year $\mathrm{t}$ after training, standard errors in parentheses. The coefficients correspond to marginal effects (as well as the re-calculated standard errors) of the censored LHS variable (see eq. 3 in text).

LHS $=$ employment days in calendar year (0-365).

${ }^{29}$ Age at entry in Foundation or redundancy, respectively. 
Table 4: Employment gains (days per year) of trainees vs. controls one to five years after training $^{30}$

\begin{tabular}{|c|c|c|c|c|c|}
\hline Period & $\mathbf{N}$ & $\begin{array}{c}\text { Mean } \\
\text { employment } \\
\text { days per year }\end{array}$ & Tobit & Tobit - IV-1 & Tobit - IV-2 \\
\hline Year $\mathrm{t}+1$ & 9622 & 209.72 & $\begin{array}{l}40.13 \\
(5.05)\end{array}$ & $\begin{array}{c}86.32 \\
(16.10)\end{array}$ & $\begin{array}{c}45.92 \\
(23.37)\end{array}$ \\
\hline Year $t+2$ & 8718 & 226.77 & $\begin{array}{l}51.90 \\
(4.95)\end{array}$ & $\begin{array}{c}98.63 \\
(16.57)\end{array}$ & $\begin{array}{l}96.38 \\
(24.76)\end{array}$ \\
\hline Year $t+3$ & 7895 & 236.09 & $\begin{array}{l}55.14 \\
(6.07)\end{array}$ & $\begin{array}{l}107.73 \\
(18.84)\end{array}$ & $\begin{array}{l}97.07 \\
(28.64)\end{array}$ \\
\hline Year $\mathrm{t}+4$ & 7010 & 247.93 & $\begin{array}{l}43.22 \\
(7.09)\end{array}$ & $\begin{array}{c}90.88 \\
(23.45)\end{array}$ & $\begin{array}{c}98.41 \\
(34.84)\end{array}$ \\
\hline Year $t+5$ & 6073 & 257.71 & $\begin{array}{l}25.92 \\
(8.33)\end{array}$ & $\begin{array}{c}77.90 \\
(34.73)\end{array}$ & $\begin{array}{l}98.08 \\
(50.94)\end{array}$ \\
\hline
\end{tabular}

\footnotetext{
${ }^{30}$ Same control variables as in Table 5, standard errors in parentheses. The coefficients correspond to marginal effects (as well as the re-calculated standard errors) of the censored LHS variable (see eq. 3 in text).

LHS $=$ employment days in calendar year (0-365)
} 
Table 5: Wage gains of trainees vs. controls (average effects in year one to five after training) $)^{31}$

\begin{tabular}{|c|c|c|c|c|c|}
\hline Group & $\mathbf{N}$ & $\begin{array}{c}\text { Mean wage } \\
\text { growth compared } \\
\text { to base year }\end{array}$ & Tobit & $\begin{array}{c}\text { Tobit - } \\
\text { IV-1 }\end{array}$ & $\begin{array}{c}\text { Tobit - } \\
\text { IV-2 }\end{array}$ \\
\hline All & 24572 & 0.047 & $\begin{array}{c}0.052 \\
(0.006)\end{array}$ & $\begin{array}{c}0.065 \\
(0.017)\end{array}$ & $\begin{array}{c}0.072 \\
(0.022)\end{array}$ \\
\hline Men & 20702 & 0.030 & $\begin{array}{c}0.050 \\
(0.006)\end{array}$ & $\begin{array}{c}0.060 \\
(0.017)\end{array}$ & $\begin{array}{c}0.059 \\
(0.023)\end{array}$ \\
\hline Women & 3870 & 0.139 & $\begin{array}{c}0.023 \\
(0.019)\end{array}$ & $\begin{array}{c}0.046 \\
(0.076)\end{array}$ & $\begin{array}{c}0.034 \\
(0.091)\end{array}$ \\
\hline Age $<22^{32}$ & 6601 & 0.111 & $\begin{array}{c}0.118 \\
(0.014)\end{array}$ & $\begin{array}{c}0.129 \\
(0.037)\end{array}$ & $\begin{array}{c}0.185 \\
(0.054)\end{array}$ \\
\hline Age $22-26$ & 7900 & 0.072 & $\begin{array}{c}0.081 \\
(0.011)\end{array}$ & $\begin{array}{c}0.150 \\
(0.031)\end{array}$ & $\begin{array}{c}0.070 \\
(0.045)\end{array}$ \\
\hline Age $27-36$ & 6892 & 0.013 & $\begin{array}{c}0.004 \\
(0.009)\end{array}$ & $\begin{array}{c}0.067 \\
(0.025)\end{array}$ & $\begin{array}{c}0.094 \\
(0.030)\end{array}$ \\
\hline Age $>36$ & 3179 & -0.073 & $\begin{array}{c}-0.056 \\
(0.012) \\
\end{array}$ & $\begin{array}{c}-0.051 \\
(0.026)\end{array}$ & $\begin{array}{c}0.001 \\
(0.035) \\
\end{array}$ \\
\hline \multicolumn{6}{|l|}{ Previous Wage } \\
\hline $1^{\text {st }}$ quartile & 6141 & 0.183 & $\begin{array}{c}0.150 \\
(0.017)\end{array}$ & $\begin{array}{c}0.219 \\
(0.052)\end{array}$ & $\begin{array}{c}0.236 \\
(0.058)\end{array}$ \\
\hline $2^{\text {nd }}$ quartile & 6141 & 0.090 & $\begin{array}{c}0.042 \\
(0.011)\end{array}$ & $\begin{array}{c}0.058 \\
(0.026)\end{array}$ & $\begin{array}{c}0.055 \\
(0.034)\end{array}$ \\
\hline $3^{\text {rd }}$ quartile & 6151 & -0.049 & $\begin{array}{l}-0.008 \\
(0.009)\end{array}$ & $\begin{array}{c}0.037 \\
(0.022)\end{array}$ & $\begin{array}{c}0.030 \\
(0.027)\end{array}$ \\
\hline $4^{\text {th }}$ quartile & 6144 & -0.171 & $\begin{array}{c}0.012 \\
(0.009)\end{array}$ & $\begin{array}{l}-0.059 \\
(0.022)\end{array}$ & $\begin{array}{l}-0.059 \\
(0.034)\end{array}$ \\
\hline
\end{tabular}

\footnotetext{
${ }^{31}$ Same control variables as in Table 4 plus 4 dummies for the year after training, plus variables in new job: white-collar, part-time, \# of previous jobs. Standard errors in parentheses.

LHS = growth in real monthly income relative to base year in the steel firm.

${ }^{32}$ Age at entry in Foundation or redundancy, respectively.
} 
Table 6: Wage gains of trainees vs. controls one to five years after training ${ }^{33}$

\begin{tabular}{|c|c|c|c|c|c|}
\hline Period & $\mathbf{N}$ & $\begin{array}{l}\text { Mean wage growth } \\
\text { compared to base year }\end{array}$ & Tobit & $\begin{array}{c}\text { Tobit - } \\
\text { IV-1 }\end{array}$ & $\begin{array}{c}\text { Tobit - } \\
\text { IV-2 }\end{array}$ \\
\hline Year $t+1$ & 5820 & -0.027 & $\begin{array}{c}0.075 \\
(0.011)\end{array}$ & $\begin{array}{c}0.040 \\
(0.029)\end{array}$ & $\begin{array}{c}0.045 \\
(0.041)\end{array}$ \\
\hline Year $\mathrm{t}+2$ & 5335 & 0.018 & $\begin{array}{c}0.053 \\
(0.012)\end{array}$ & $\begin{array}{c}0.072 \\
(0.032)\end{array}$ & $\begin{array}{c}0.085 \\
(0.045)\end{array}$ \\
\hline Year $t+3$ & 4934 & 0.057 & $\begin{array}{c}0.050 \\
(0.012)\end{array}$ & $\begin{array}{c}0.057 \\
(0.031)\end{array}$ & $\begin{array}{c}0.096 \\
(0.039)\end{array}$ \\
\hline Year $t+4$ & 4474 & 0.095 & $\begin{array}{c}0.072 \\
(0.015)\end{array}$ & $\begin{array}{c}0.121 \\
(0.038)\end{array}$ & $\begin{array}{c}0.181 \\
(0.048)\end{array}$ \\
\hline Year $\mathrm{t}+5$ & 4009 & 0.129 & $\begin{array}{c}0.057 \\
(0.017)\end{array}$ & $\begin{array}{c}0.156 \\
(0.064)\end{array}$ & $\begin{array}{c}0.150 \\
(0.084)\end{array}$ \\
\hline
\end{tabular}

\footnotetext{
${ }^{33}$ Same control variables as in Table 2 plus variables in new job: white-collar, part-time, \# of previous jobs. Individuals close to social security ceiling $(-2 \%)$ in the base year excluded, standard errors in parentheses.

LHS $=$ growth in real monthly income relative to base year in the steel firm.
} 
a) Steel firms $\mathrm{A}$

(including matched wage restraint)

b) Steel firms B

(excluding matched wage restraint)

Remaining Workforce

(wage restraint)

Trainees themselves

(interest from severance pay

+ opportunity costs for lost earnings)

Public subsidies

(direct subsidies + longer benefit duration

+ lost tax receipts)

a) Wage gain: $5 \%$ over 30 years, discounted by $4 \%$

b) Wage gain: 5\% over 10 years, discounted by $4 \%$

Employment gain: +45 days over 10 years discounted by $4 \%$

Tax gains induced by wage (scheme a) and employment gains, marginal tax rate including contributions for unemployment and health

insurance

Reduced unemployment benefits induced by increased employment of trainees

\footnotetext{
${ }^{34}$ See the text for the used assumptions and approximations.
} 
Figure 1: Concept and timing in the Foundation

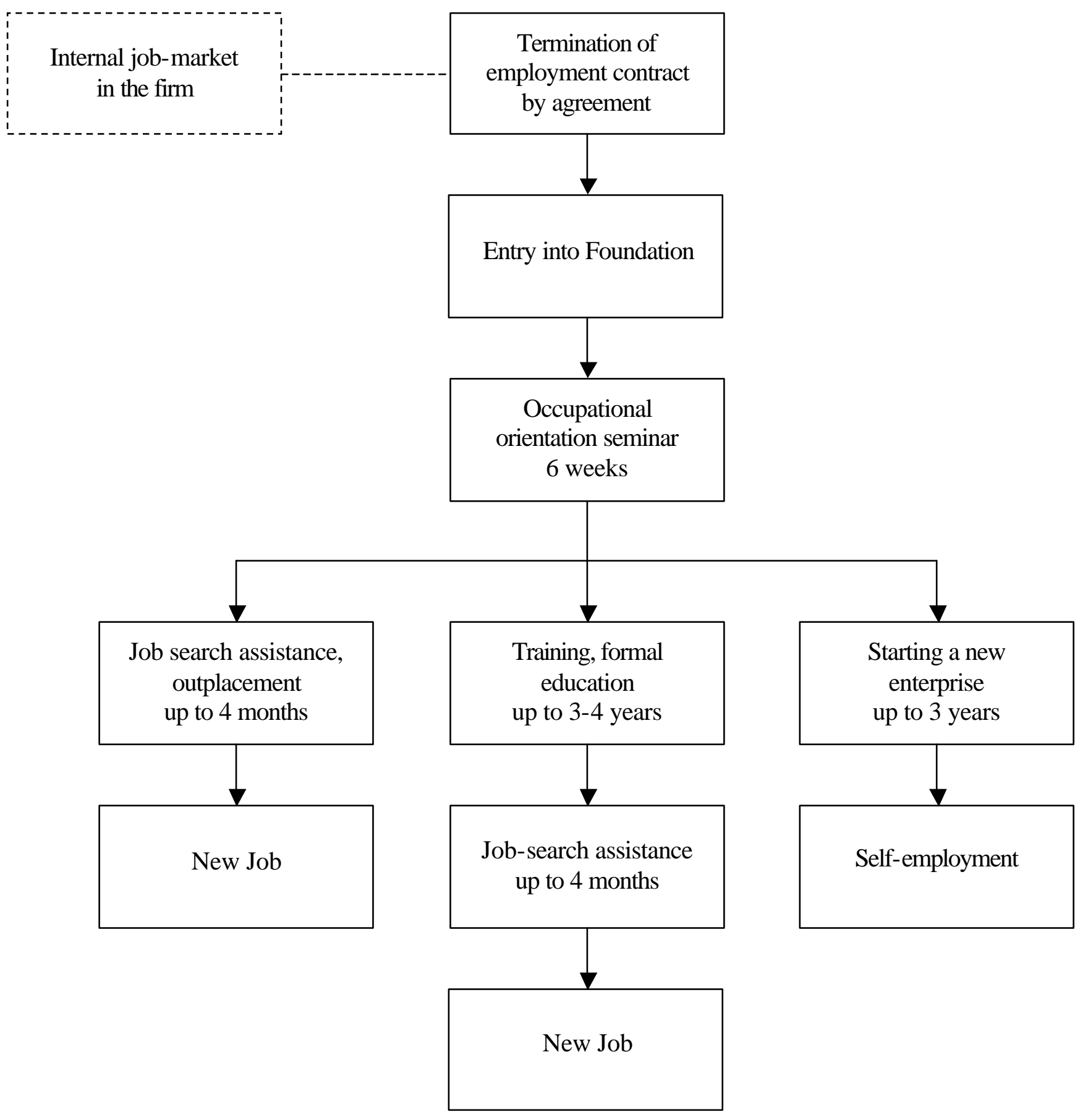

Source: Steel Foundation, 1996 


\section{Figure 2: Sampling design}

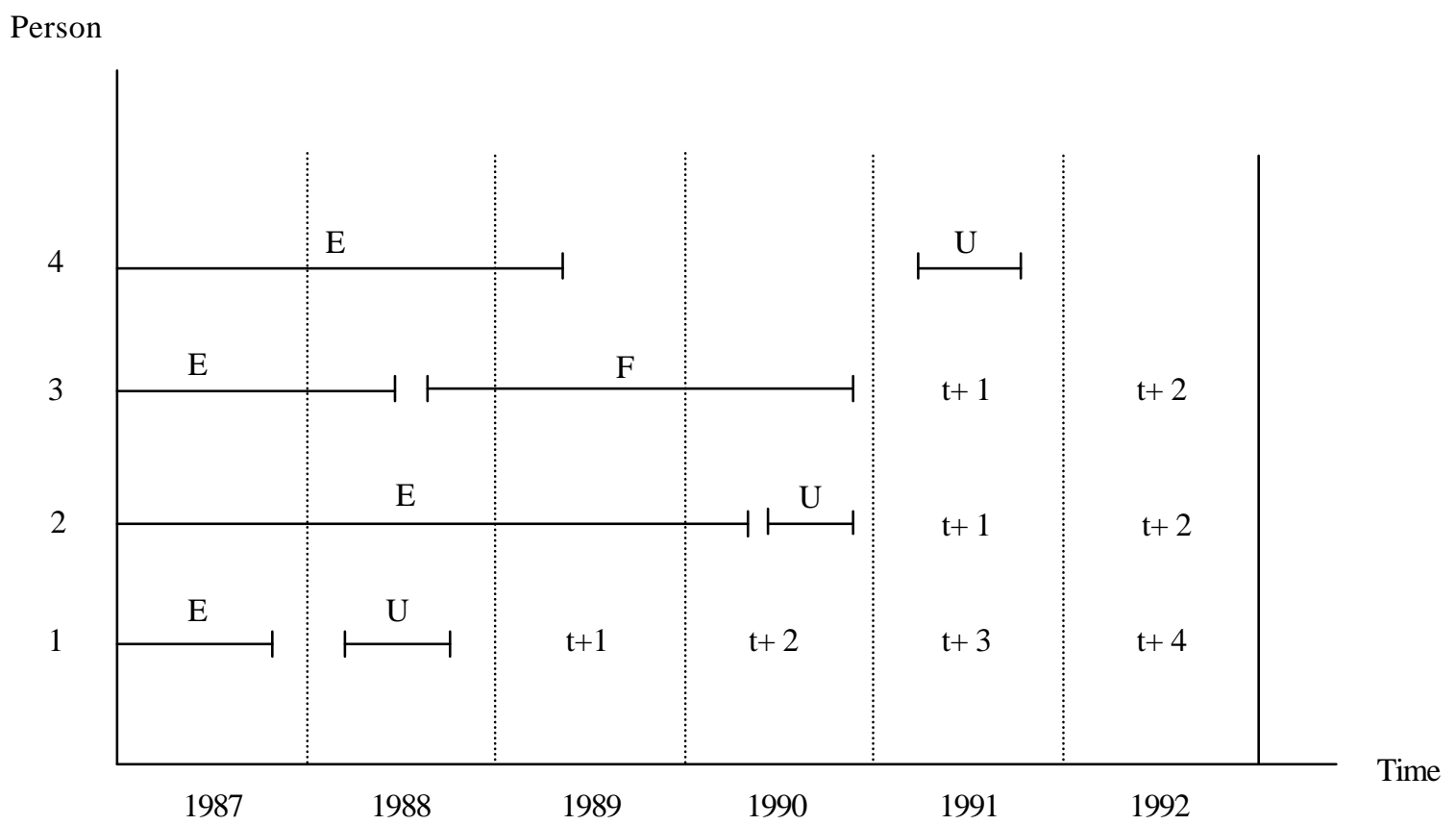

$\mathrm{E}=$ employment spell in steel firm, $\mathrm{U}=$ unemployment spell, $\mathrm{F}=$ trainee in Foundation, $+1=$ first year after Foundation or redundancy, respectively. Person 3 is a trainee, persons land 2 are part of the control group, person 4 is not. 


\section{References:}

Angrist, Joshua D., Guido W. Imbens and Don B. Rubin: Identification of Causal Effects Using Instrumental Variables, Journal of the American Statistical Association 91, 1996, 444-455.

Blumberger, Walter, Nemeth, Dietmar and Hans Reinsprecht: Analyse der Zugangsproblematik und der Selektionskriterien zu Kursen der Arbeitsmarktverwaltung, 1993, mimeo, Institut für Berufs- und Erwachsenenbildung, Linz.

Card, David: Using Geographic Variation in College Proximity to Estimate the Return to Schooling, NBER working paper \#4483, 1993.

Card, David: The Causal Effect of Education on Earnings, in: Orley Ashenfelter and David Card (eds.), Handbook of Labor Economics, Volume 3, Amsterdam (North-Holland), 2000.

Dar, Amit and Indermit S. Gill: Evaluations of Retraining Programs in OECD countries: Implications for Economies in Transition, The World Bank, Report IDP-156, 1995.

Dary, Jeanette A., Anderson, Joe S. and Nicholas DiMarco: Outcome Comparisons of Formal Outplacement Services and Informal Support, Human Ressource Development Quarterly 6-3, 1995, 275-288.

Davis, Steven J., Haltiwanger, John C. and Scott Schuh: Job Creation and Destruction, The MITPress (Cambridge, MA), 1996.

Decker, Paul T. and Walter Corson: International Trade and Worker Displacement: Evaluation of the Trade Adjustment Assistance Program, Industrial and Labor Relations Review 48, 1995, $758-774$.

DellaVigna, Stefano and Daniele M. Paserman: Job Search and Hyperbolic Discounting, mimeo, Harvard University, November 2000.

Dipplinger, Erich: Die Studie Arbeitsstiftungen: Stellungnahme aus der Sicht der von der Stahlstifung betreuten Unternehmen, in: Lechner, Ferdinand and Walter Reiter (eds.): Arbeitsstiftungen, Erfahrungen und Entwicklungsperspektiven, Wissenschaftsverlag (Wien), 1991, 81-82.

Eder, Johannes: Die Arbeitsstiftung als arbeitsmarktpolitisches Instrument, Masters thesis, University of Business and Economics, Vienna, 1997.

Emerson, Michael: Regulation or Deregulation of the Labor Market, European Economic Review 32, 1988, 775-817.

Fersterer, Josef and Rudolf Winter-Ebmer: Are Austrian Returns to Education Falling Over Time, CEPR Discussion Paper 2313, London, 2000. 
Fitzenberger, Bernd and Stefan Speckesser: Zur wissenschaftlichen Evaluation der Aktiven Arbeitsmarktpolitik in Deutschland: Ein Überblick, ZEW Discussion Paper 00-06, Mannheim, 2000.

Heckman, James, LaLonde, Robert and Jeffrey A. Smith: The Economics and Econometrics of Active Labor Market Programs, in: Ashenfelter, Orley and David Card (eds.), Handbook of Labor Economics, Vol. III, North-Holland (Amsterdam), 2000.

Heckman, James: Policies to Foster Human Capital, Research in Economics 54, 2000, 3-56.

Heckman, James, Lochner, L. and Chris Taber: General Equilibrium Treatment Effects: A Study of Tuition Policy, American Economic Review 88, 1998, 381-386.

Ichino, Andrea and Rudolf Winter-Ebmer: Lower and Upper Bounds of Returns to Schooling: An Exercise in IV Estimation with Different Instruments, European Economic Review 43, 1999, 889-901.

Kerz, Sebastian: Bewältigung der Stahlkrisen in den USA, Japan und der EU, Vandenhoeck \& Ruprecht (Göttingen). 1991.

Lechner, Ferdinand and Walter Reiter (eds.): Arbeitsstiftungen, Erfahrungen und Entwicklungsperspektiven, Wissenschaftsverlag (Wien), 1991.

Long, Scott: Regression Models for Categorical and Limited Dependent Variables, Sage Publications (Thousand Oaks), 1997.

Martin, John P.: What works among Active Labour Market Policies: Evidence from OECD Countries' Experience, OECD Economic Studies 30, 2000, 79-113.

Nigsch, Otto: Effekte der Stahlstiftung, beabsichtigte und nichtbeabsichtigte, mimeo, Linz, 1995.

Seckauer, Hansjörg: Arbeitsstiftungen, eine Analyse von Arbeitsstiftungen in Braunau und Vöcklabruck, mimeo, Linz, part I, 1997.

Steininger, Karl: Die praktische Relevanz der Stahlstiftung beim Personalabbau in der verstaatlichten Industrie, Masters thesis, University of Linz, 1993.

Winter-Ebmer, Rudolf and Josef Zweimüller: Manpower Training and Employment Stability, Economica, 63, 1996, 113-130.

Winter-Ebmer, Rudolf: Benefit Duration and Unemployment Entry: Quasi-Experimental Evidence for Austria, mimeo, CEPR Discussion Paper \#1521, December 1996.

Winter-Ebmer, Rudolf: Potential Unemployment Benefit Duration and Spell Length: Lessons from a Quasi-Experiment in Austria, Oxford Bulletin of Economics and Statistics, 1998, 33-46.

Winter-Ebmer, Rudolf: Long-term Consequences of an Innovative Redundancy-retraining Project: The Austrian Steel Foundation, Social Protection DP 0103, The World Bank, 2001. 


\section{IZA Discussion Papers}

\section{No Author(s)}

191 G. C. Giannelli

C. Monfardini

192

G. Brunello

193

A. Kunze

194

A. Newell

F. Pastore

195

F. Büchel

A. Mertens

196 J. S. Earle

K. Z. Sabirianova

197

G. A. Pfann

198 M. Kreyenfeld

C. K. Spiess

G. G. Wagner

199 H. Entorf

200

T. Bauer

G. S. Epstein

I. N. Gang

201

T. J. Dohmen

G. A. Pfann

202

P. Francois

J. C. van Ours

203 J. M. Abowd

F. Kramarz

D. N. Margolis

T. Philippon

204

G. S. Epstein
Titel

Area

Date

Joint Decisions on Household Membership and Human Capital Accumulation of Youths: The role of 5 $8 / 00$ expected earnings and local markets

Absolute Risk Aversion and the Returns to

5

$8 / 00$

Education

The Determination of Wages and the Gender

Wage Gap: A Survey

5

$8 / 00$

Regional Unemployment and Industrial

Restructuring in Poland

4

$8 / 00$

Overeducation, Undereducation, and the Theory

of Career Mobility

Equilibrium Wage Arrears: A Theoretical and 4

Empirical Analysis of Institutional Lock-In

Options to Quit

$9 / 00$

A Forgotten Issue: Distributional Effects of Day

3

$9 / 00$

Care Subsidies in Germany

Rational Migration Policy Should Tolerate Non-

Zero Illegal Migration Flows: Lessons from

Modelling the Market for Illegal Migration

What are Migration Networks?

$9 / 00$

Worker Separations in a Nonstationary Corporate 1 Environment

$9 / 00$

Gender Wage Differentials in a Competitive Labor 5

$9 / 00$

Market: The Household Interaction Effect

The Tail of Two Countries: Minimum Wages and 5 Employment in France and the United States

$9 / 00$ Labor Market Interactions Between Legal and
Illegal Immigrants

Temporary Jobs: Stepping Stones or Dead Ends? 1
$10 / 00$

$10 / 00$

M. Francesconi

J. Frank 
206 C. M. Schmidt

R. Baltussen

R. Sauerborn

207

C. M. Schmidt

208

J. Hartog

R. Winkelmann

209 M. Barbie

M. Hagedorn

A. Kaul

210 T. J. Dohmen

211 A. van Soest

M. Das

X. Gong

212 X. Gong

A. van Soest

P. Zhang

213 X. Gong

A. van Soest

E. Villagomez

214 X. Gong

A. van Soest

215 J. Ermisch

M. Francesconi

216 F. Büchel

217 J. Hansen

R. Wahlberg

218 C. Dustmann

A. van Soest

219 F. Kramarz

T. Philippon

220 W. A. Cornelius

E. A. Marcelli
The Evaluation of Community-Based Interventions: Group-Randomization, Limits and Alternatives

Arbeitsmarktpolitische Maßnahmen und ihre

Dutch Migrants in New Zealand:

$10 / 00$

Did they Fare Well?

Dynamic Effciency and Pareto Optimality in a

3

$10 / 00$

Stochastic OLG Model with Production and Social

Security

Housing, Mobility and Unemployment

$11 / 00$

A Structural Labour Supply Model with

5

$11 / 00$

Nonparametric Preferences

Sexual Bias and Household Consumption: A

5

$11 / 00$

Semiparametric Analysis of Engel Curves in Rural China

Mobility in the Urban Labor Market: A Panel Data Analysis for Mexico

Family Structure and Female Labour Supply in Mexico City

The Effect of Parents' Employment on Children's

5

$11 / 00$

Educational Attainment

The Effects of Overeducation on Productivity in

5

$11 / 00$

Germany - The Firms' Viewpoint

Occupational Gender Composition and

Wages in Sweden

5

Parametric and Semiparametric Estimation in

$11 / 00$ Models with Misclassified Categorical Dependent Variables

The Impact of Differential Payroll Tax Subsidies on Minimum Wage Employment

The Changing Profile of Mexican Migrants to the United States: New Evidence from California and Mexico 

former Soviet Union to Israel: Who is coming when? and Earnings: An Empirical Study for Portugal Selection

234 R. Rotte M. Steininger

Sozioökonomische Determinanten extremistischer 3 Wahlerfolge in Deutschland: Das Beispiel der Europawahlen 1994 und 1999 
236 R. Hujer

M. Caliendo

237 S. Klasen

I. Woolard

238 R. Euwals

A. Börsch-Supan

A. Eymann

239 F. Andersson

K. A. Konrad

240 W. Koeniger

241 W. Koeniger

242 G. Faggio

J. Konings

243 E. Brainerd

244 S. M. Fuess, Jr. M. Millea

245 F. Andersson

K. A. Konrad

246 E. Plug W. Vijverberg

247 E. Plug W. Vijverberg

248 P. M. Picard

E. Toulemonde

249 B. M. S. van Praag

P. Cardoso

250 T. J. Hatton

J. G. Williamson
Evaluation of Active Labour Market Policy:

Methodological Concepts and Empirical

Estimates

Surviving Unemployment without State Support: 3

$12 / 00$

Unemployment and Household Formation in

South Africa

The Saving Behaviour of Two Person House-

5

$12 / 00$

holds: Evidence from Dutch Panel Data

Human Capital Investment and Globalization in

5

$01 / 01$

Extortionary States

Labor and Financial Market Interactions: The Case of Labor Income Risk and Car Insurance in the UK 1969-95

Trade, Labor Market Rigidities, and GovernmentFinanced Technological Change

Job Creation, Job Destruction and Employment Growth in Transition Countries in the 90's

4

Economic Reform and Mortality in the Former

4 Soviet Union: A Study of the Suicide Epidemic in the 1990s

Pay and Productivity in a Corporatist Economy:

5

01/01

Evidence from Austria

Globalization and Human Capital Formation

5

$01 / 01$

Schooling, Family Background, and Adoption:

5

01/01

Does Family Income Matter?

Schooling, Family Background, and Adoption:

5

$01 / 01$

Is it Nature or is it Nurture?

The Impact of Labor Markets on Emergence and 2

$01 / 01$

Persistence of Regional Asymmetries

"Should I Pay for You or for Myself?"

3

$01 / 01$

The Optimal Level and Composition of

Retirement Benefit Systems

Demographic and Economic Pressure on

Emigration out of Africa 
254 H. Gersbach

A. Schniewind

255 H. Gersbach

A. Schniewind

Learning of General Equilibrium Effects and the

The Times They Are A-Changin': 
